EARNINGS AND CAPITAL MANAGEMENTIN ALTERNATIVE LOANLOSS PROVISION REGULATORY REGIMES

Daniel Pérez, Vicente Salas and Jesus Saurina.

Documentos de Trabajo. N. 0614

baneo españa
2006

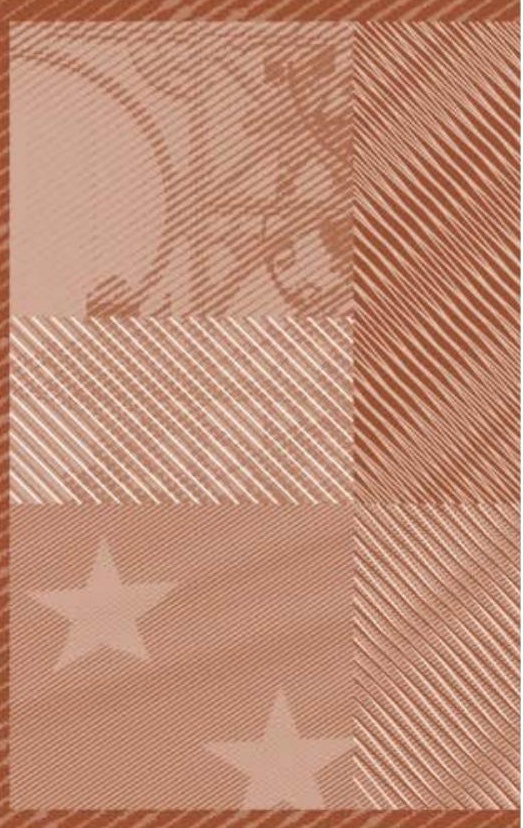


EARNINGS AND CAPITAL MANAGEMENT IN ALTERNATIVE LOAN LOSS PROVISION REGULATORY REGIMES 
EARNINGS AND CAPITAL MANAGEMENT IN ALTERNATIVE LOAN

LOSS PROVISION REGULATORY REGIMES $\left.{ }^{*}\right)$

\section{Daniel Pérez}

BANCO DE ESPAÑA

Vicente Salas

UNIVERSIDAD DE ZARAGOZA AND BANCO DE ESPAÑA

Jesús Saurina $\left(^{\star *}\right)$

BANCO DE ESPAÑA

(*) This paper is the sole responsibility of its authors and the views represented here do not necessarily reflect those of the Banco de España. We thank the many comments and suggestions received to previous versions of the paper from

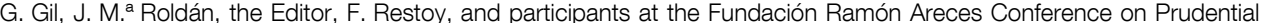
Regulation and Banking Supervision, in particular, those from J. C. G. Céspedes, X. Freixas, C. A. E. Goodhart, M. Gordy, I. Peña, R. Repullo, J. C. Rochet and H. S. Shin, and at the Foro de Finanzas. The last revision of the paper has benefited a lot from detailed comments and suggestions from Larry Wall. Any errors that remain are, however, entirely the authors' own.

$\left.{ }^{\star \star *}\right)$ Address for correspondence: Jesús Saurina; C/ Alcalá, 48, 28014 Madrid, Spain. Tel. + 3491338 5080; e-mail: jsaurina@bde.es. 
The Working Paper Series seeks to disseminate original research in economics and finance. All papers have been anonymously refereed. By publishing these papers, the Banco de España aims to contribute to economic analysis and, in particular, to knowledge of the Spanish economy and its international environment.

The opinions and analyses in the Working Paper Series are the responsibility of the authors and, therefore, do not necessarily coincide with those of the Banco de España or the Eurosystem.

The Banco de España disseminates its main reports and most of its publications via the INTERNET at the following website: http://www.bde.es.

Reproduction for educational and non-commercial purposes is permitted provided that the source is acknowledged.

\section{@ BANCO DE ESPAÑA, Madrid, 2006}

ISSN: 0213-2710 (print)

ISSN: 1579-8666 (on line)

Depósito legal: M.29659-2006

Imprenta del Banco de España 


\begin{abstract}
The paper sets an accounting and behavioral framework from which we derive a reduced-form equation to test income smoothing and capital management practices through loan loss provisions (PLL) by Spanish banks. Spain offers a unique environment to perform those tests because there are very detailed rules to set aside loan loss provisions and they are not counted as regulatory capital. Using panel data econometric techniques, we find evidence of income smoothing through PLL but not of capital management. The paper draws some lessons for accounting rule setters and banking regulators regarding the current changes in the accounting framework (introduction of IFRS/IAS in Europe) as well as the new capital framework (Basel II). In particular, a very detailed set of rules to set aside loan loss provisions does not prevent managers from decreasing earnings volatility, similarly to what happens in a more principles-oriented accounting framework.
\end{abstract}

JEL: G18, G21.

Keywords: income smoothing, capital management, IFRS/IAS, Basel II. 


\section{Introduction}

Banks use loan loss provisions to create reserves in order to cover the expected (latent, inherent or incurred and not yet individually identified) losses embedded in their loan portfolios. In theory, the accrual of loan loss provisions in the income statement of banks should be exclusively dictated by credit risk considerations. But, in practice, loan loss provisions are, in many countries, left to the judgment of banks' managers and, therefore, they are one of the important items of the income statement subject to discretionary managerial decisions [Beatie et al. (1995), World Bank (2002)]. Although the debate on whether earnings management by banks or any company contributes to market efficiency or distorts investors decisions in a non-efficient way is still open [Goel and Thakor (2003)], it is well understood that regulatory decisions alter the managerial incentives to perform such actions.

The new accounting framework based on International Accounting Standards (IAS), renamed International Financial Reporting Standards (IFRS), and the implementation of the new capital framework (Basel II) will significantly change the regulatory environment of European banks. The IFRS/IAS framework is a step forward in the direction of less detailed rules and more principles in the elaboration of accounting statements. The discussion on principles versus rules was fuelled by some large accounting scandals, as in Enron, where many argued that under a principles based system, the auditors would have been forced to evaluate the economic substance of Enron's transactions rather than merely certify that the firm had complied with a series of detailed rules. Basel II will make capital requirements more risk sensitive. Moreover, Basel II raises the issue of the purpose of regulatory capital (i. e. if it should be used to cover unexpected or expected and unexpected losses) and, more specifically, the issue of whether loan loss reserves should be included or not as part of regulatory capital. Research on determinants of the current loan loss provisions decisions by banks in different regulatory environments can help evaluate the likely consequences of changes in the regulatory framework of banks in income smoothing and capital management practices.

This paper examines the causes and consequences of the use of loan loss provisions to manage earnings and capital by banks with two main contributions. First, the paper explicitly models the process that determines the reduced-form equation used to test income smoothing and capital management. This provides theoretical foundations to some of the empirical specifications used in previous work, and helps to properly identify the explanatory variables used in the tests. It also provides direct comparisons of the incentives to smoothing in countries, including the US, where general loan loss reserves are currently included as part of tier 2 regulatory capital, and the case of Spain where provisions are excluded from capital. To our knowledge this is the first time that such formal comparison is performed.

Second, the paper presents empirical evidence about the practice of income smoothing and capital management in Spain, where loan loss reserves are excluded from regulatory capital. Spanish banks will have different costs and benefits of managing profit and/or capital than, for example, US banks. Most of the existing evidence on use of loan loss provisions to manage income and capital refers to the US [Beaver et al. (1989); Moyer (1990); Scholes, Wilson and Wolfson (1990); Beatty, Chamberlain and Magliolo (1995); 
Collins, Shackelford and Wahlen (1995); Beaver and Engel (1996); Kim and Kross (1998); Ahmed, Takeda and Thomas (1999)] ${ }^{1}$. The comparison with what happens in a country with different regulatory regime can help to better anticipate the impact of future regulatory changes.

In Spain the regulation of loan loss provisions is made by the Central Bank (Banco de España), which dictates strict rules on how such provisions have to be accrued and, in principle, it leaves little room for managerial discretion. If evidence is found that banks get away from strict accounting rules and use loan loss provision decisions to manage earnings or capital, then to have very detailed rules may be irrelevant, and there is a point in having more principles-oriented accounting standards. Likewise, in year 2000, the Banco de España introduced the so-called "statistical provision" aimed at, during good times, force banks to set aside provisions for the expected losses that are embedded in their expanding credit portfolios and, during bad times, allowing to use the reserve to cover realized losses [Fernández de Lis, Martínez and Saurina (2000)]. This is a very unique regulatory experience since it introduces a countercyclical loan loss provision that, by construction, smoothes net income over time. Our behavioral model predicts that, under income smoothing, general and specific loan loss provisions should be more dependent on the true credit risk of loans and less dependent on net operating income after the statistical provision was introduced than what they were before. The paper provides an empirical test of this prediction.

Besides the interest of the research questions and the fact that we provide evidence on important issues from a different accounting and banking regulatory framework than previous work, the paper contributes to the literature on positive accounting and bank regulation around loan loss provision decisions in other ways. First, the estimation of the empirical model is made with the appropriate panel data techniques to control for endogeneity or simultaneity of some of the explanatory variables (i .e. instrumental variables and, in particular, GMM estimators), as well as for potential biases due to the correlation between explanatory variables and regression residuals. Such estimation techniques, as in Kang and Sivaramakrishnan (1995) that apply them to non-financial firms, prove very relevant to avoid biases in the estimations. Secondly, thanks to the theoretical analysis, the paper points out that lagged regulatory capital, beginning of the year, and not contemporary capital, end of the year, as most of the papers have used in the past, is the proper explanatory variable to use in models that test capital management. Loan loss provisions of period $t$ affect the retained earnings of period $t$ and, therefore, the capital of the bank at the end of the year. This can create spurious correlation that distorts the results of the tests.

Using bank level annual data for the period 1986 to 2002 we find robust evidence that, despite the detailed set of rules for loan loss provisions and the exclusion of general provisions from regulatory capital, there has been income smoothing among Spanish banks. Therefore, a detailed set of rules for provisioning does not curtail managers' discretion and, thus, the final result is not too far away from that obtained in an accounting framework governed by principles that allow, in general, for more discretion. Secondly, no evidence is found of capital management in the sense that Spanish banks do not condition the loan loss provision decision to the level of the regulatory capital at the beginning of the period.

1. Some exceptions would be Shrieves and Dahl (2003) who study the case of Japanese banks and Laeven and Majnoni (2003) who analyze loan loss provision decisions in a sample of several countries. Anandarajan, Hasan and Lozano-Vivas (2003) study the Spanish case although the sample period (1986-1995), the hypotheses and the econometric approach (OLS) are quite different from those we present in this paper. 
Thus, there is a separation between loan loss provisions and capital. Finally, evidence is found that the statistical provision is in fact an income smoothing device so that, after its introduction in year 2000, Spanish banks set their non statistical provisions (general and specific) with higher weight in credit risk variables and less weight in net operating income, than in years before.

The rest of the paper is organized as follows. Section 2 presents a brief summary of the regulation of loan loss provisions and reserves in Spain and the regulatory framework that is introduced by IFRS/IAS and Basel II. Section 3 presents the basic models that relate loan loss provisions with net operating income and capital under different behavioral assumptions on earnings and capital management. Section 4 explains the econometric framework used to test income smoothing and capital management as well as the database. In section 5 we present the results of the empirical analysis. The discussion of the results, section 6 , and the conclusions, section 7 , closes the paper. 


\section{The accounting and regulatory frameworks}

One important risk for banks is credit risk. Banks use loan loss provisions to create reserves in order to cover the expected losses embedded in their loan portfolios. In many countries, including the US, the amount of specific and general loan loss provisions is left to managers' judgement. However, in a few countries, Spain among them, the loan loss provisions are subject to very detailed rules and, in principle, managers have little discretion to alter them [Beattie et al. (1995), World Bank (2002)].

Loan loss provisions might be counted as regulatory bank capital. In the US, as well as in other countries (I e. G-10 countries), general loan loss reserves are included as part of Tier 2 regulatory capital. Basel I, the current capital framework, considers that general loan loss reserves are tier 2 capital up to $1.25 \%$ of risk-weighted assets. Therefore, bank managers might have incentives to use loan loss provisions to alter regulatory capital ratios. However, in Spain they are not counted either as tier 1 or tier 2 capital. National banking supervisors can tighten Basel rules and that has been the case for Spain regarding loan loss provisions.

Basel II [BCBS (2004)] advocates for some changes in the definition of capital. The final framework states that for those banks using the IRB approach (i. e. the approach that allows for the use of the own risk measurement from the internal models of the banks), expected losses should be fully covered with all loan loss provisions and that, in case of shortfall it is deducted $50 \%$ from tier 1 and $50 \%$ from tier 2. The excess provision over expected losses can be recognized as tier 2, up to $0.6 \%$ of the risk-weighted assets. Banks in the standardised approach (i. e. an extension of the current Basel I capital requirements to incorporate rating agencies assessment of the riskiness of exposures) will apply the current $1.25 \%$ risk-weighted-assets approach. In the Basel II final framework capital aims at covering unexpected losses whilst loan loss provisions are devoted to expected losses. Thus, the purpose and definition of bank regulatory capital has been open to discussion, and in particular the role played by loan loss provisions.

The question is whether detailed rules can effectively limit management discretion in decisions such as how much loan loss provisions accrue in the income statement of the bank, and to what extent the incentives and the impact of bank managers' discretion depends on the aim and definition of regulatory capital. Although with some mixed results, there are plenty of references in the literature of accounting and finance showing that, in fact, managers use loan loss provisions to "manage" earnings and/or capital ${ }^{2}$. Those that view earnings management as a practice that disguises the true economic value of firms and sends distorted signals to the investors and any stakeholder of the company, would express their concerns if accounting reforms and the change in the regulatory capital framework spur more discretion in managerial decisions with respect to loan loss provisions.

Spain is a unique environment to test income smoothing and capital management and, thus, to answer the question set in the former paragraph since there are very detailed rules for setting aside loan loss provisions and, moreover, they are not counted as regulatory capital. Regarding the specific provision, for impaired loans (i. e. 90 days overdue)

2. See, for example, Beaver and Engel (1996), Moyer (1990), Beatty, Chamberlain and Magliolo (1995), Ahmed, Takeda and Thomas (1999), Kim and Kross (1998). 
between 3 and 6 months overdue, the provision was $10 \%$ of the current amount overdue; between 6 and 12 months, 25\%; between 12 and 18 months 50\%; between 18 and 21 months, 75\%; and for those more than 21 months overdue, 100\%. Specific provisions for impaired mortgages (loan to value up to $80 \%$ ) were different (up till 3 years past due, there was no provision requirement; between 3 and 4 years, 25\%; between 4 and 5 years, 50\%; between 5 and 6 years, 75\%; and 100\% for those past due 6 years). If a loan had been in arrears for one year, the provision was applied to the whole amount due, not only to the installments overdue. Moreover, if the $25 \%$ of the due amount was overdue, the whole outstanding amount of the loan had to be used in order to calculate the specific provision for that loan. In addition, there were thresholds and linkages between several facilities that were pertaining to the same customer in order to determine the final coverage. For example, if a borrower had several loans from a bank, when the overdue amount reached the $25 \%$ of the total due amount of the borrower, the specific provision had to be set aside based on that whole amount, and not only on the overdue loans. Regarding general provisions, they were set either at the $1 \%$ of new loans (unimpaired) or at the $0.5 \%$ for (unimpaired) mortgages (with LTV up to 80\%).

The former prescriptive rules are in sharp contrast with the discretion that bank managers enjoy in many other countries. On top of that, Spain is also known for being the only country that has developed and started to apply (from July 2000 onwards) a dynamic provision (the so-called statistical provision). A detailed explanation of its rational, objectives and mechanism is in Fernandez de Lis, Martínez and Saurina (2000) ${ }^{3}$. Essentially, during good times, Spanish banks have to set aside provisions for the expected losses that are embedded in expanding credit portfolios. The provisions made during those years are used to build up the socalled statistical fund that might be depleted in bad times when the excesses of the last upturn appear in the form of impaired assets. The former is achieved by comparing every quarter the latent loss in the credit portfolio (i. e. a fixed parameter times the exposure) with the amount of specific provisions (which fluctuates significantly along the business cycle). That difference, if positive, is charged into the P\&L whereas, if negative, is written as income in the P\&L statement (provided that the statistical reserve has been previously build up).

By design, the dynamic provision produces flat loan loss provision ratios (i. e. loan loss provisions over total loans) through the economic cycle. It might be of interest to see if such a provision, with a clear stated objective and a transparent mechanism (i. e. banks must disclose separately the amount of the statistical provision), has altered the behavior of Spanish banks in terms of income and earnings management. As Laeven and Majnoni (2003) indicate, the regulation of bank capital and loan loss reserves has to consider the incentives of banks to take into account macroeconomic shocks, together with the idiosyncratic ones in their loan loss provision decisions. This paper is interested in investigating if differences in loan loss provisions regulations and changes in regulation over time within a country affect the incentives of banks to manage income and capital. The next section presents the behavioral background that will guide the empirical analysis.

3. Laeven and Majnoni (2003) link this provision with the cyclical oscillations of bank reserves proposed by Holmstrom and Tirole (2000). 


\section{Earnings and capital management}

We start with models that link loan loss provision decisions to income smoothing objectives and the indirect implications for the evolution of regulatory capital over time. Next, we model the loan loss provision decision if banks have additional purposes in terms of meeting regulatory capital standards. Finally, we model the implications for income smoothing of introducing the statistical provision.

\subsection{Earnings management}

One of the primary objectives of earnings management (accounting practices that depart consciously from established accounting rules and principles in the computation of accounting profits) is income smoothing, a practice aimed at reducing the variability of net profits over time. During good years managers use some discretionary items in the profit and loss account in order to decrease the amount of profits. During bad times, those funds can be used to prop up the bottom line.

The existing literature provides several explanations about why firms smooth earnings. Barnea, Ronen and Sadan (1975) and Ronen and Sadan (1981) consider smoothing a signaling device; Beaver et al. (1989), Whalen (1994), Ahmed, Takeda and Thomas (1999) apply this idea to explain loan loss provisions decisions of US banks. Moral hazard and agency theory explanations of smoothing earnings can be found in Lambert (1984), multiperiod agency, and in Fudemberg and Tirole (1995) ${ }^{4}$. Trueman and Titman (1988) attribute income smoothing to perceived bankruptcy concerns and Rozycki (1997) to ways to take advantage of the tax code. For Goel and Thakor (2003) smoothing is the consequence of managers trying to increase share prices by reducing the potential loss that shareholders face when they trade for liquidity reasons.

Banks may practice income smoothing because they are affected by some of the situations listed above but also for other reasons specific to the banking firm. Banks are subject to minimum capital requirements and income smoothing can be the result of accounting practices aimed at meeting these requirements. Moreover, at least in many countries, bank managers have high discretion in determining the amount of loan loss provisions to accrue in the income statement of the period, so loan loss provisions offer a unique opportunity for income smoothing among banks, [Kim and Santomero (1993), Wall and Kock (2000)].

The purpose of this section of the paper is to draw behavioral implications of income smoothing with loan loss provision decisions when they respond to general reasons and when they respond to capital management purposes in particular.

Define by $P L L_{t}=f\left(C R_{t}\right)$ the provision for loan losses that should be accrued by the bank in period $t$ as a function of the credit risk of the portfolio $(C R)$ and as a function of the regulatory rules on loan loss provisions. Define CPL $L_{t}$ as the actual or current provision charged by the bank in period $t^{5}, P T$ as the actual profit of the bank and $P A_{t}=\left(N O I_{t}-P L L_{t}\right)(1-u)$ the actual profit of the bank in case the provision for loan losses

4. The agency framework is also present in Dye (1988), Schipper (1989) and Evans and Sridhar (1996).

5. The CPLL are the Spanish equivalent to the provision for loan and leases losses (PLLL) in the US accounting framework. 
responds only to credit risk considerations, where $\mathrm{NOI}_{t}$ is the net operating income (before loan loss provisions), also in period t, and, finally, $u$ is the tax rate on profits. We say that current provisions on loan losses obey to income smoothing when the difference between CPLLt and $P L L_{t}$ can be explained by the difference between the profit target of the bank $P T$ and the actual profit, $P A_{t}$. Formally, the income smoothing practice will explain provisions on loan losses when,

$$
C P L L_{t}-P L L_{t}=-\beta_{1}\left(P T-P A_{t}\right)
$$

with $\beta_{1}>0$ being the parameter that determines the speed of adjustment towards the profit target. The adjustment will be positive (negative) when non-smoothed profit is above (below) the profit target. Substituting $P A_{t}$ and $P L L_{t}$ for their respective values defined above and after rearranging the terms we have,

$$
C P L L_{t}=\alpha_{0}+\alpha_{1} f\left(C R_{t}\right)+\alpha_{2} N O I_{t}
$$

where $\alpha_{0}=-\beta_{1} P T ; \alpha_{1}=1-\beta_{1}(1-u) ; \alpha_{2}=\beta_{1}(1-u)$

The use of loan loss provisions for income smoothing purposes implies that the current provision will be a linear combination of the provision determined only by credit risk considerations and of the net operating income of the period.

Although it may not intend to do so, income smoothing will also affect the evolution of capital of the bank through its effect on the flow of retained earnings, $R E_{t}$. To see this, we calculate the $R E$ of the bank in period t for a given dividend payment of $D / V_{t}$ :

$$
R E_{t}=\left(N O I_{t}-C P L L_{t}\right)(1-u)-D I V_{t}
$$

Substituting (2) in (3), we obtain:

$$
R E_{t}=-\alpha_{0}(1-u)-(1-u) \alpha_{1} f\left(C R_{t}\right)+(1-u)\left(1-\alpha_{2}\right) N O I_{t}-D I V_{t}
$$

Retained earnings will change with net operating income, NOI, by a factor of $(1-u)$ if the bank does not practice income smoothing, (i. e. $\beta_{1}=\alpha_{2}=0$ ), and with a factor of $(1-u)\left(1-\alpha_{2}\right)$ if there is income smoothing. Given that $\alpha_{2}>0$ (since $\beta_{1}>0$ ), income smoothing weakens the relationship between $\mathrm{NO}$ and retained earnings (tier 1 capital) over time. In other words, income smoothing reduces the contribution of profits to regulatory capital by an amount, per unit of profits, of $(1-u) \alpha_{2}$ compared with the contribution with no income smoothing of $(1-u)$.

In the Spanish case loan loss reserves are excluded from regulatory capital. However, given that Basel I allow to do so, in the US, as well as in many other countries, general loan loss reserves are counted as tier 2 capital (up to a limit). Now, the change in regulatory capital of period $t$ will be the result of earnings retention and general loan loss provisions also in period t. Let $\chi$ (between 0 and 1 ) be the proportion of 
general loan loss provisions over total provisions, that is, general and specific ${ }^{6}$. Changes in regulatory capital from increases in reserves and provisions during period $t$ will be,

$$
R E_{t}+\chi C P L L_{t}=N O I_{t}(1-u)-C P L L_{t}(1-u)-D I V_{t}+\chi C P L L_{t}
$$

Substituting (2) in (5), we have:

$R E_{t}+\chi C P L L_{t}=\alpha_{0}(\chi-1+u)+(\chi-1+u) \alpha_{1} f\left(C R_{t}\right)+\left(1-u+(\chi-1+u) \alpha_{2}\right) N O I_{t}-D I V_{t}$

Now, a marginal change in net operating income, NOI, will imply a change in regulatory capital, tier $1+$ tier 2 , of $\left[1-u+(\chi-1+u) \alpha_{2}\right]=\left[1-u-(1-u-\chi) \alpha_{2}\right]$. When loan loss provisions are part of the regulatory capital, income smoothing lowers the marginal contribution of $\mathrm{NOI}$ to capital in the amount of $(1-u-\chi) \alpha_{2}$, compared with the marginal contribution with no income smoothing of $(1-u)$. Notice that if $\chi$ is larger than $(1-u)$ income smoothing actually increases the marginal contribution of $N O /$ to capital, compared with the contribution with no income smoothing?. When general loan loss provisions are excluded as part of regulatory capital, income smoothing lowers the marginal contribution of net operating income to capital, compared with the contribution when they are included, by an amount of $\chi \alpha_{2}$. However, excluding loan loss provisions from regulatory capital increases the fixed component of retained earning resulting from income smoothing, compared with that when they are included, by the amount $\alpha_{0}=\chi \beta_{1} P T$.

The final conclusion is that the effect of income smoothing on the level of regulatory capital from changes in the regulation on loan loss reserves being part of regulatory capital or not, is undetermined Importantly, if there is no income smoothing, $\alpha_{2}=0$, the definition of regulatory capital is irrelevant in terms of the impact of the evolution of $\mathrm{NO}$ on bank regulatory capital.

We summarize the results on income smoothing as follows:

Result 1.a) The use of loan loss provisions to smooth earnings implies that current loan loss provisions will be determined by a linear combination of credit risk factors and of net operating income of the period.

1.b) Banks that use loan loss provisions to smooth earnings weaken the relation between net operating income and regulatory capital, compared with the situation with no smoothing. The cost of income smoothing, in terms of lower contribution to regulatory capital through retained earnings, when loan loss reserves are included as part of regulatory capital compared with that when they are excluded, is undetermined.

1.c) If there is no income smoothing, the impact of net operating income on capital through retained earnings is the same regardless of the definition of bank regulatory capital (i. e. in the US and in Spain).

These results have an important corollary. If banks care about the induced effects of income smoothing in the evolution of regulatory capital over time, we cannot be sure of the

6. Indirectly, assuming $\chi$ constant means that it is independent of the extent to which the bank engages in income smoothing.

7. If we consider only tier 1 , then income smoothing has the same cost in terms of reduced retained earnings when loan loss reserves are not part of tier 2 capital than when they are. Here we assume that the relevant regulatory capital is tier 1 plus tier 2 . 
net costs of income smoothing in terms of the contribution of retained earnings to regulatory capital of one regulatory capital regime or the other.

\subsection{Capital management}

The reasons why banks hold capital are manifold [Berger, Herring and Szegö (1995)]. Holding capital reduces the probability of bankruptcy and therefore the so-called costs of failure, which include the loss of charter value, reputation loss, compliance with existing compulsory capital requirements and legal costs of the bankruptcy process [Acharya (1996)]. Higher capital levels reduce the probability of not complying with those requirements thus minimizing the consequent costs (restrictions on the current activities of the bank, on the future growth prospects, on the payment of dividends or immediate capitalization). Changing the capital level entails adjustment costs. Apart from pure transaction costs, the main adjustment costs include those related to the problem of asymmetric information in capital markets. As the issuer has an informational advantage over the potential buyers, issuing stocks can be seen as a signal that the company considers that market prices are above the true share value, which would increase the cost of the desired adjustment [Myers and Majluf (1984) and Winter (1994)].

The effect of income smoothing on regulatory capital, as shown in the previous subsection, may force banks to condition smoothing to meeting capital requirements. On the other hand, banks can use loan loss provision decisions to manage regulatory capital directly.

Define by $\mathrm{C}^{\star}$ the target in regulatory capital set by the bank to comply with minimum capital requirements and by $\mathrm{C}_{t}$ the regulatory capital of the bank at the end of the period if there is no smoothing and loan loss provisions are determined exclusively as a function of credit risk. In the Spanish case, once the dividend policy is fixed, banks can only change the regulatory capital through retained earnings. To use loan loss provisions to manage capital means, in this context, that banks decide the current loan loss provision of the period so that retained earnings contribute to reduce the distance between the target and the level of regulatory capital resulting from no management decisions,

$$
R E\left(C P L L_{t}\right)-R E\left(P L L_{t}\right)=\beta_{2}\left(C^{*}-C_{t}\right)
$$

with $\beta_{2}>0$.

Given that $\mathrm{RE}(\mathrm{CPLL} t)=\left(\mathrm{NOI}_{t}-\mathrm{CPLL} t\right)(1-\mathrm{u})-\mathrm{DIV}_{\mathrm{t}} ; \mathrm{RE}\left(\mathrm{PLL} \mathrm{L}_{\mathrm{t}}\right)=\left(\mathrm{NOI}_{\mathrm{t}}-\mathrm{PLL} \mathrm{t}\right)(1-\mathrm{u})-$ $D_{I V} ; P L L_{t}=f\left(C R_{t}\right) ;$ and $C_{t}=\left(C_{t-1}+(1-u)\left(N_{1} l_{t}-P L L_{t}\right)-D I V_{t}\right)$, we obtain from (7),

$$
C P L L_{t}=-\beta_{2}\left(C^{\star}+D I V_{t}\right)+\left(1-\beta_{2}(1-u)\right) f\left(C R_{t}\right)+\beta_{2}(1-u) N O I_{t}+\beta_{2} C_{t-1}
$$

Capital management in the way described implies that current loan loss provisions are determined as the weighted sum of credit risk factors $\left[f\left(C R_{t}\right)\right]$, net operating income of the period $\left(N O I_{t}\right)$ and regulatory capital at the beginning of the period $\left(C_{t-1}\right)$.

If capital regulation of banks includes general loan loss reserves as part of the regulatory capital, banks can use retained earnings together with loan loss provisions to meet capital objectives. If $C L$ indicates capital plus general loan loss reserves, we can write,

$$
\left(R E\left(C P L L_{t}\right)+\chi C P L L_{t}\right)-\left(R E\left(P L L_{t}\right)+\chi P L L_{t}\right)=\beta_{2}\left(C L^{*}-C L_{t}\right)
$$


and substituting in (9) $R E\left(C P L L_{t}\right)$ and $R E\left(P L L_{t}\right)$ by their values given above, we have,

$$
C P L L_{t}=\frac{-\beta_{2}}{1-u-\chi}\left(C L^{\star}+D I V_{t}\right)+\left(1-\beta_{2}\right) f\left(C R_{t}\right)+\frac{\beta_{2}(1-u)}{1-u-\chi} N O I_{t}+\frac{\beta_{2}}{1-u-\chi} C L_{t-1}
$$

The sign of $(1-u-\chi)$ can be positive or negative and the absolute value of $1 /(1-u-\chi)$ is greater than 1 . Therefore, when loan loss provisions are part of regulatory capital, capital management implies indeterminacy in the sign of the association between current loan loss provisions and net operating income and regulatory capital. When the proportion of general over total provisions is high, $\chi>(1-u)$, the association between beginning of the period capital and current loan loss provisions will be negative under capital management. Usually, specific provisions are relatively larger in economic downturns, when impaired loans (i. e. past due and doubtful assets) increase substantially. During upturns, general provisions are more prevalent. Therefore, under regulatory regimes that include general provisions in regulatory capital the use of loan loss provisions to manage capital will imply a positive association between current loan loss provisions and beginning of the period capital in economic downturns and a negative association between the two in upturns ${ }^{8}$.

Result 2.a) If banks use loan loss provisions to manage capital then current total loan loss provisions will be positively correlated with beginning of the period regulatory capital in regulatory regimes where loan loss reserves are excluded from regulatory capital.

2.b) On the other hand, when general loan loss reserves are included as part of the regulatory capital, capital management implies a positive (negative) association between the two variables when the proportion of general reserves over total reserves is lower (higher) than one minus the tax rate.

2.c) Capital management through loan loss provisions implies that current loan loss provisions will be a function of net operating income even in cases where there is no earnings management. The sign of the association is the same that the sign of the association between current provisions and start of the period regulatory capital but the absolute value of the association will be lower by a factor of $(1-u)$.

\subsection{Statistical provision}

In this section we explore the implications, for the behavioral models of loan loss provisions outlined above, of the statistical provision which was described in more detail in section 2.

Let $\mathrm{SP}_{\mathrm{t}}$ be the statistical provision that a bank accrues in period t. This provision increases in periods of higher relative credit growth, economic expansions, and it decreases in periods of low growth, recessions, when general and specific provisions are not sufficient to cover the increase in bad loans due to defaults. Therefore, the statistical provision is in itself counter-cyclical and contributes to smooth profits over the business cycle.

8. Moyer (1990) points out that when loan loss reserves are part of regulatory capital a dollar increase in loan loss provisions increases regulatory capital by the tax rate. Therefore, the relationship between current loan loss provisions and regulatory capital at the beginning of the year will be negative. Our model differs from this result because, consistent with Basel I regulation on capital, we make the distinction between general and specific provisions and only the later can be part of tier 2 capital. Our model is consistent with the prediction of a negative association between total loan loss provisions and regulatory capital when $\chi=1$. In this case the coefficient $\frac{\beta_{2}}{1-u-\chi}$ will be $-\beta_{2} / u$, consistent with Moyer's result. Thus, the presentation above is consistent with current Basel I capital regulation that limits the inclusion in tier 2 capital to general loan loss reserves. 
Our interest is to study how the statistical provision modifies the decisions on the accrual of general and specific provisions (CPLL) by Spanish banks.

Equation (1) is now formulated as:

$C P L L_{t}-P L L_{t}=-\beta_{3}\left(P T-P A_{t}^{\prime}\right)$

where $P T$ is the (unchanged) profit target after the new provision and $P A^{\prime}$ is the profit level under the assumption that there is no smoothing and net of the statistical provision, $P A_{t}^{\prime}=\left(N O I_{t}-P L L_{t}\right)(1-u)-S P_{t}$, since the statistical provision is not tax deductible. The profit target is assumed the same since the expected impact of the statistical provision is zero across an entire business cycle.

The statistical provision is calculated as the difference between the proportion $k$ of the total loans at the end of the period, $L_{t}$, and the specific provision accrued by the bank under no smoothing, $S P_{t}=k L_{t}-(1-\chi) P L L_{t}$.

Substituting $S P_{t}$ and $P A^{\prime}$ in (11) we have,

$C P L L_{t}=-\beta_{3} P T+\left(1-\beta_{3}(-u+\chi)\right) f\left(C R_{t}\right)+\beta_{3}(1-u) N O I_{t}-\beta_{3} k L_{t}$

Under income smoothing, the introduction of the statistical provision implies that banks set generic and specific loan loss provisions (CPLLt) as a function (positive) of $\mathrm{NO}$ and as a function (negative) of the stock of loans $L$. Since both, net operating income and loans, are variables that capture the volume of activity of the bank, the positive and negative signs of their respective coefficients will tend to net out. Loan loss provisions will now depend relatively more of the credit risk, the coefficient of $f\left(C R_{t}\right)$ is higher than before the statistical provision by an amount equal to $\beta_{3}(1-\chi)$, and less on the cyclical activity of the bank. In fact, assuming that net operating income, $N O$, is proportional to total loans, $L$, by a factor of $m$, $N O I=m L$, then (12) can be written as,

$C P L L_{t}=-\beta_{3} P T+\left(1-\beta_{3}(-u+\chi)\right) f\left(C R_{t}\right)+\beta_{3}\left(1-u-\frac{k}{m}\right) N O I_{t}$

Therefore, we have the following result.

Result 3. If banks smooth income, the introduction of the statistical provision lowers the weight of the $\mathrm{NOI}$ variable in determining the current general and specific provisions accrued by each bank, and increases the weight of credit risk variables when the proportion of general reserves $\chi$ is less than one ${ }^{9}$.

9. For given values of the parameters $u, k$ and $m$ the sign of the weight placed in the NOI variable can even be negative. 


\section{Econometric model and data set}

The empirical model assumes that banks decide about specific and general provisions, CPLL, with the purposes of covering credit risk, smoothing income and possibly managing capital. From equation (10) above the general empirical model is formulated as follows:

$C P L L_{i t}=\alpha+\delta f(C R E D I T \quad R I S K)+\beta N_{i t}+\gamma C_{i t-1}+\mu$ Control Variables $+\eta_{i}+\varepsilon_{i t}$

Where $\alpha, \delta, \beta, \gamma, \mu$ are are parameters to be estimated. The null hypothesis is that $\beta$ and $\gamma$ are equal to zero (i. e. banks do not use loan loss provisions to manage profits and/or capital). These hypotheses are made under the premise that, in Spain, loan loss provisions are highly regulated through detailed rules and, thus, there is no discretion for bank managers in deciding about them.

Equation (14) resembles the empirical model used in the literature either to test for income smoothing, to test for capital management, or both. Greenawalt and Sinkey (1988), Ma (1988) and Wetmore and Brick (1994) all regress loan loss provisions on current net operating income, non-performing loan ratios and some additional variables as credit portfolio structure. The empirical literature on banks usually analyses both income smoothing and capital management at the same time. Ahmed, Takeda and Thomas (1999) regresses loan loss provisions on earnings before provisions and tier 1 capital before loan loss reserves. A similar equation and explanatory variables are used in Beatty, Chamberlain and Magliolo (1995), Collins, Shackelford and Wahlen (1995) and Moyer (1990), although as a part of a multiple equation framework where other discretionary items are also considered. Wahlen (1994) and Kim and Kross (1998) focus only on loan loss provisions and charge-offs simultaneously ${ }^{10}$. Greenawalt and Sinkey (1988); Ma (1988); Scholes, Wilson and Wolfson (1990); Whalen (1994); Collins Shackelford and Wahlen (1995); and Kim and Kross (1998) find evidence on income smoothing with loan loss provisions whilst Wetmore and Brick (1994), and Ahmed, Takeda and Thomas (1999) reject it. For the US regulatory framework, capital management might also imply $\gamma<0$ when the proportion of general provisions is high, as we showed before. Moyer (1990), Beatty, Chamberlain and Magliolo (1995) and Ahmed, Takeda and Thomas (1999) find evidence of a negative relationship between capital and loan loss provisions for US banks. Kim and Kross (1998) find evidence of capital management in low capitalized banks.

Once the credit risk and control variables are made explicit the empirical model to be estimated is formulated as follows:

$$
\begin{aligned}
& C P L L_{i t}=C+\delta_{1} N P L_{i t}+\delta_{2} I B O L_{t}+\delta_{3} L T A_{i t}+\delta_{4} G D P G_{t}+ \\
& +\beta_{1} N O I_{i t}+\beta_{2} N O I_{i t} \times R E G 00+\gamma C A P_{i t-1}+\mu S I Z E_{i t}+\eta_{i}+\varepsilon_{i t}
\end{aligned}
$$

10. Beaver et al. (1989); Wahlen (1994); Beaver and Engel (1996) and Liu, Ryan and Wahlen (1997) focus on the impact of loan loss provisions on the market value of the banks, distinguishing between the discretionary and the non-discretionary components of PLL. 
The dependent variable $C P L L_{i t}$ is the value of net specific and general loan loss provisions of bank $i$ in year $t$. The variable is normalised by the total assets of the bank to avoid spurious size effects in the explanation of provisions.

The variables that proxy the credit risk of the bank, CR, are NPL, IBOL, LTA and GDPD. The variable NPL measures the doubtful assets of bank $i$ in period $t$, according to its balance sheet data; the variable is normalised by the total assets of the bank. IBOL is the general index of stocks listed in the Madrid Stock exchange also in year $\mathrm{t}$; it is intended to capture expectations about future economic conditions which can affect the current loan loss provision decisions of banks. LTA, the ratio of total loans to total assets, is a proxy for the risk profile of the bank. The more loans to the retail or the corporate sector, the higher the risk tolerance of bank managers (the alternative is to buy far safer Spanish government bonds or to lend to other Spanish banks). GDPG is the rate of growth of Spanish Gross Domestic Product in year $t$. It is intended to capture the effect of macroeconomic conditions (business cycle) on loan loss provisions, beyond the risk profile of a particular bank. The inclusion of an explicit measure of the business cycle offers us the possibility of testing the cyclical pattern of CPLL, when controlling for other explanatory variables. The strong cyclical pattern of loan loss provisions was one of the prudential arguments used by Banco de España to create he statistical provision ${ }^{11}$, coupled with the well known fact that credit risk mistakes are made during good times when over optimism is pervasive and credit standards are relaxed [Crockett (1997), Rajan (1994), Manove and Padilla (1999), and Jiménez and Saurina (2006)]. Coefficients of NPL and LTA are expected to be positive and those of IBOL and GDPG negative.

The variable $\mathrm{NOI}$ is the net operating income (profits before provisions and extraordinary items) of bank $\mathrm{i}$ in period $\mathrm{t}$, normalised by total assets of the bank. Earnings and/or capital management practices predict a positive and significant value for the coefficient of this explanatory variable (Results 1.a and 2.c). The cross effect variable NOI $\times$ REGOO, where REGOO is a dummy variable that takes the value of 1 if the observation belongs to the period before year 2000 and 0 otherwise, allows for changes in the weight of $\mathrm{NO}$ variable after the statistical provision is introduced. The model predicts a negative sign for the oefficient of this variable, i. e. the statistical provision reduces the weight of $N O I$ in the determination of general and specific provisions (Result 3).

The variable CAP is the total capital ratio of the bank at the start of period $t$ (end of period $t-1$ ). The numerator does not include the general loan loss provision and the denominator is the risk-weighted assets (RWA). Capital management practices that under Spanish regulation exclude loan loss provisions from regulatory capital imply a positive coefficient for this variable ${ }^{12}$.

The variable SIZE is the log of total assets. It is included as a control variable. We do not have any strong ${ }^{13}$ a priori about the expected sign, although credit portfolio diversification would point towards a negative sign for $\mu$.

11. Laeven and Majnoni (2003) are also interested in testing the cyclical pattern of loan loss provisions. More generally, during Basel II discussions, the issue of procyclicality of capital requirements has risen a lot of attention. Taylor and Goodhart (2004) contains a good summary of that discussion as well as many references. Notice that procyclicality of loan loss provisions would increase additionally the pressure on bank capital during bad times.

12. Some papers test for capital management using unweighted total assets due to the lack of data on RWA.

13. Hughes et al. (1996) explain the advantages and disadvantages of diversification in terms of risk. 
Finally, $\eta_{i}$ reflects unobserved bank individual characteristics that are constant along time. Among those characteristics, it should be included the bank risk profile. Credit policies are not changed from one day to the other. Usually, they are deeply established and permeate the whole banking organisation. Therefore, it is possible to assign to each bank a kind of characteristic risk profile that defines its particular way to manage credit risk. $\varepsilon i t$ is the random error.

Model (15) is estimated with the DPD package developed by Arellanao and Bond (1988). Variables are in differences to control for unobserved bank individual effects. Since CPLL and some of the explanatory variables, NPL, NOI, LTA, CAP, can be jointly determined we make use of the Arellano and Bond (1991) GMM estimator for NPL, LTA, CAP and $\mathrm{NO} /$ using as instruments two and three-year lags of these four variables.

The data come from accounting statements of consolidated banking groups from 1986 till 2002. The time period covers almost two full business cycles in Spain. We focus on consolidated data because capital requirements are calculated at a group level, irrespective that each individual bank has to have satisfactory available capital. Both commercial and savings banks have been included, representing more than 95\% of total market share of credit institutions. Only foreign bank branches and credit co-operatives have been excluded. Our panel is unbalanced since new institutions have started to operate during the period considered while others have ceased to exist.

Under these premises and after eliminating a series of institutions with extremely atypical data (due essentially to the specific nature of their business), an unbalanced panel has been obtained comprising up to 142 banks over a period of up to 17 years, totaling 1449 observations. Table 1 shows the descriptive statistics of the variables. 


\section{Results}

Model 1 of Table 2 contains the results of the estimation of equation (15) in first differences. The results are the one-step estimates robust to heteroskedasticity provided by DPD. As expected, there is autocorrelation of first order but not of second order (through differentiation we have created artificially autocorrelation of first order in the residuals). The test of adequacy of instruments (Sargan test) is also satisfactory.

The coefficients of the credit risk proxy variables all have the expected sign. The coefficient of non-performing loans over total assts, NPL, is positive and significant the $1 \%$ level. Similar results are obtained for the coefficient of loans over total assets, LTA, positive and significant. IBOL and GDPD have negative estimated coefficients but only the coefficient of the GDP growth variable is statistically significant at 5\%. Expectations from the Stock market do not affect current loan loss provision decisions of banks, after controlling for the rest of the variables. On the other hand, the business cycle affects loan loss provision decisions of banks, in a countercyclical way, even after controlling for the bank level risk variables, such as NPL and LTA. The control variable SIZE does not have a significant effect on loan loss provisions.

The positive and significant coefficient of $\mathrm{NOI}$ does not reject the hypothesis that Spanish banks practice income smoothing through their loan loss provision decisions (Result 1.a). However, the negative and significant coefficient of NOIxREGOO implies that smoothing is less important in determining the general and specific loan loss provisions after year 2000, when the statistical provision is in place. This confirms Result 3 and indicates that the statistical provision provides banks with a smoothing device that substitutes old smoothing practices through general and specific provisions. Model 2 shows the results when the estimation is restricted to the period 1989-1999, when the statistical provision was not in place. The coefficient of $N O /$ is the same as that shown in Model 1 for the period 1989-2002 (0.166 and 0.169, respectively). From Model 1 the coefficient of $\mathrm{NOI}$ in the period $2000-2002$ is $0.075(0.169-0.094)$, less than halve the value in the previous period ${ }^{14}$.

On the other hand, the parameter of the total capital ratio lagged one-year, $C A P$, is not significantly different from zero. This is true in Model 1 and in Model 2. Therefore, there is no evidence of capital management through loan loss provisions in Spain (Result 2.a is rejected). The result is robust to alternative measures of capital, tier 1 (CAPT1) in Model 3 and capital buffer (BUF) in Model 4 in Table $2^{15}$. Importantly, the income smoothing results continue to hold when we use the alternative definitions for the capital variable.

A relevant issue is to test if the smoothing behaviour is symmetric in periods of expansion and contraction. Model 5 of Table 2 presents evidence in this respect by allowing

14. Note that in Model 2 the coefficient of NPL is lower than in Model 1 (0.116 compared to 0.127$)$. This is consistent with Result 3 that predicts an increase in the weight of risk factors in determining loan loss provisions after the statistical provision. However, when we estimate the model with REG00xNPL as an additional explanatory variable then the coefficient of this variable is not statistically different from zero. During the high GDP growth period of 2000-2002 the proportion of general loan loss provisions is quite high.

15. The capital buffer is calculated as the difference between the current regulatory capital held by the bank and its minimum required capital, in terms of the latter one. A detailed discussion of the determinants of that buffer is in Ayuso, Pérez and Saurina (2004). 
changes in the parameter of $\mathrm{NO}$ in periods when current profits before provisions are above the long term value of profits (average value of $\mathrm{NOI}$ over the period for each) and when current profits are below the long term value. The positive coefficient of the variable $A B S\left(N O I_{i t}-N O I_{i}\right)$, although only significant at the $14 \%$ level, indicates that banks seem to increase the discretion on loan loss provisions relative to earnings in periods where profits are relatively high, while in periods when profits are relatively low the effect decreases significantly.

\subsection{Robustness analysis}

Model 1 of Table 3 contains the estimation of equation (15) augmented by including the endogenous variable lagged one period as an explanatory variable. As mentioned in section 2, specific provisions evolve in Spain according to a calendar linked to the past due age of the non-performing loans. Therefore, it seems reasonable to expect that today's loan loss provisions will be highly correlated to those of last year. To have the lagged endogenous variable in the right hand side obliges us to use an additional GMM estimator for that variable. It is instrumented with two and three lags.

As in Model 1 of Table 2, there is residual autocorrelation of first order and not of the second order. The Sargan test is satisfactory. As expected, the lagged endogenous variable is positive and significant. Regarding the other variables, there is almost no change. $N P L$ and $L T A$ have positive and significant estimated coefficients. The strong cyclicality of provisions remains, although now is only significant at the $10 \%$ level. Expectations from the Stock market are not significant, as before. More importantly, the lack of capital management hypothesis holds as well as the non-rejection of the income smoothing one.

Model 2 in Table 3 shows the result of the estimation of (15) using the contemporaneous capital ratio instead of the lagged one year capital ratio ${ }^{16}$. In that case, all the former results hold. However, the parameter of the capital ratio is now negative and statistically significant. Recall that in Spain, given that general loan loss provisions are not counted as tier 2, the expected sign for the capital ratio under capital management is positive and the proper capital measure to use is the capital ratio lagged one year, not the end of the year value. Our interpretation of the negative coefficient of the contemporaneous capital ratio is that the ratio is determined after the loan loss provisions of the period are accrued in the income statement. Higher loan loss provisions imply lower retained earnings in the period and lower capital at the end of the period. Therefore the negative sign is spurious and casts doubts on the true interpretation that should be given to negative signs obtained in other papers that use contemporary capital ratios.

16. Some papers in the literature use the contemporaneous capital ratio as such or before loan loss reserves, but after retained earnings to test for capital management. 


\section{Regulatory policy lessons}

The first lesson is for accounting rule setters and bank supervisors. It seems that despite the set of very detailed rules governing provisioning in Spain, in sharp contrast with the discretion in many other countries, managers have had discretion to adjust its level as a function of the level of income. Thus, very detailed rules for loan loss provisions do not seem to deter banks from using them as a discretionary device to moderate earnings volatility, similarly to the empirical evidence in countries with accounting frameworks more principles-oriented. Therefore, if the discretion by bank managers is a concern for banking supervisors, the only deterrent might be detailed disclosure, not detailed rules for setting aside provisions. The former might allow investors and bank analysts to estimate profits and capital of banks far better than relying in the information provided by managers. In other words, reliance in principles might be the only option left for accounting standards. However, detailed disclosure might be useful in curtailing managers' discretion, which inevitably seems to follow principles.

In that sense, the adoption by the European Union of IFRS/IAS is an step forward in the direction of more principles-oriented accounting frameworks. Moreover, the Basel II devotes a lot of attention to disclosure requirements by banks, in particular, regarding detailed information on loan loss provisioning policies, internal models and expected loss calculations (Pillar 3 of the new capital accord). Transparency, instead of detailed rules or curtailing definitions, seems to be the key stone to assessing the financial strength of a bank and the way to effectively monitor bank managers' discretion.

Secondly, banks seem to make decisions on loan loss provisions independent of capital decisions. The lack of an empirical relationship (substitution) between both variables is consistent with the presumption that banks set capital levels to cover unexpected losses (UL) while provisions are set to cover for the expected ones (EL). Definitions of regulatory capital consistent with the observed behaviour of banks should split the role of loan loss provisions and capital in terms of EL and UL coverage. In fact, if the Spanish experience can be extrapolated to other countries, banks are expected to easily adapt to Basel II proposal to, essentially, use capital for UL and total loan loss provisions for EL. If there were substitution between capital and provisions or, alternatively, if banks considered both items as equivalents, then there would be no much interest in having separate requirements for expected and unexpected losses since an increase in capital might be balanced by a decline in loan loss provisions. However, if the opposite is true, as it has been proven for Spanish deposit institutions, then supervisors should make sure that both losses are properly covered, one with loan loss provisions and the other with capital. In fact, Basel II deletes any shortfall in the coverage of EL through provisions from capital, as explained in section 2.

Accounting rule setters intend to avoid provisioning of unrealised losses since they focus on the annual profit or loss. On the other hand, banking regulators tend to regard capital buffers and provisioning of future losses as devices that might be useful to reinforce the solvency of banks and, therefore, contribute to financial stability ${ }^{17}$. The experience of the Spanish banking system shows that banks do use loan loss provisions to cover only EL (i. e. no interaction with capital). Therefore, the remaining issue is that the

17. Wall and Koch (2000) point out the different views that accounting authorities and market regulators on the one side and bank supervisors on the other side hold on this issue. 
accounting framework should allow for the full coverage of EL through loan loss provisions. If there is a maximum amount of those that can be set aside, banks will have to set aside more capital to cover the deficit. Although the latest Basel II proposal allows for that, it would be desirable that the accounting framework allowed for a more flexible response.

Thirdly, the cyclical profile of loan loss provisions is a matter of concern for many banking supervisors targeting a safe and sound banking system. If provisions focus only on realised losses, without taking into account expected losses lurking in credit portfolios and waiting for the next recession to show up, then banking fragility might increase. A dynamic provision, based on expected losses or incurred, at a portfolio level, but not yet individually identified losses (i. e. latent or inherent losses), may be a way to keep at bay the former concerns ${ }^{18}$.

Finally, from a prudential perspective, there are good arguments to defend the coverage of expected losses through loan loss provisions, as they are assumed by banks, and not to wait until losses are realised to cover them (either with specific provisions or out of the capital buffer). Does this pose a threat to transparency? The answer is no. The dynamic or statistical provision in Spain is a good example for that. It has stringent disclosure requirements so that investors and financial analysts can "undue" its impact on the profit and loss account. Banks are required to disclose the year amount of the statistical provision as well as the amount of the statistical reserve accumulated along time. Therefore, it is possible to have a prudential device, which is, at the same time, transparent. Thus, banking regulators should work closely with accounting rule setters and market supervisors in order to find a reasonable compromise between instruments that enhance banking stability without hampering transparency and investors' information. Moreover, we have provided empirical evidence that the introduction of the statistical provision decreases the smoothing purposes of general and specific provision decisions of Spanish banks. Banks' concern for smoothing earnings over time continues under the new regulatory situation but with the important difference that the statistical provision is a transparent smoothing device while the smoothing performed before was all opaque to unsophisticated analysts.

18. Jiménez and Saurina (2006) contain a practical proposal, as well as the rational for it. Benston and Wall (2004 and 2005) argue that reported net income may be biased if a bank is experiencing rapid credit growth in loans that might go bad not before several years. In that case, the recognition of some of the interest payments should be deferred until it can be matched against the related credit risk. 


\section{Conclusions}

The present paper has tested for capital management and income smoothing among Spanish banks in order to draw some lessons for accounting rule setters and banking regulators regarding current changes of the accounting framework (i. e. introduction of IFRS/IAS in Europe) and Basel II framework. The null hypotheses to be tested have been derived from a detailed analysis of the reduced model that describes the behavior of banks when they manage profits and capital. The analysis has proven useful to identify the costs and benefits of income smoothing under different regulatory regimes on whether loan loss provisions should be part of regulatory capital or not. Second, it has proven to be a useful guide when it comes to specify the empirical models that give the results of the tests.

Spain offers a unique environment to test income smoothing and capital management practices, compared with many other countries such as US, since there have been very detailed rules to set aside loan loss provisions and general loan loss provisions have not been counted as tier 2 capital. Moreover, changes in the regulatory environment such as the introduction in year 2000 of the statistical provision, that it is by itself an income smoothing device, should induce banks to reduce other, more costly, smoothing practices.

Using panel data econometric methodology, we find clear evidence of income smoothing through general and specific loan loss provisions, but no capital management, among Spanish banks. The empirical evidence is also consistent with the prediction that after the statistical provision is in place Spanish banks will reduce the importance of other loan loss provisions, specific and general, to smooth income. The absence of capital management suggests that banks follow the pattern of covering EL with provisions and UL with capital. Thus, the final version of the Basel II framework can be expected to receive the endorsement of future banking practice from countries that in the past have been subject to different capital regulations. However, a very detailed set of loan loss provision rules does not prevent managers from decreasing earnings volatility. The other lesson from the Spanish experience is that transparent smoothing devices, such as the countercyclical statistical provision, induce banks to reduce other, opaque, smoothing practices.

Some important lessons can be extracted from the former results. First of all, in the debate among accountants between principles versus detailed rules, the balance seems to tilt in favor of the former since the latter do not avoid managers' discretion. That result enhances the value and the need of detailed disclosure.

Moreover, supervisors will have to make sure that loan loss provisions properly cover expected losses and that capital is used for the unexpected ones, once the new capital framework is in place. Shortages of any of them will have to be properly addressed. That being the case, from a prudential point of view it is important to have a coherent accounting framework for banks that effectively allows loan loss provisions to fully cover expected losses. Dialog between accountants and banking supervisors might consider the parallelism between expected losses and losses incurred at a portfolio level, although not yet individually identified. The paper also confirms the pro-cyclical behavior of loan loss provisions. 
In terms of banking stability, the paper offers some evidence that the final proposal of the BCBS regarding regulatory capital definition is not going to disrupt the incentives banks have to properly set aside loan loss provisions and capital to cover losses. However, it points towards the need for an open dialogue with accountants as well as the reinforcement of disclosure requirements to enhance bank transparency and monitoring by investors of bank manager's behavior and incentives. 


\section{REFERENCES}

ACHARYA, S. (1996). "Charter Value, Minimum Bank Capital Requirement and Deposit Insurance Pricing in Equilibrium", Journal of Banking and Finance, 20, pp. 351-375.

AHMED, A. S., C. TAKEDA and S. THOMAS (1999). "Bank Loan Loss Provisions: a Re-examination of Capital Management, Earnings Management and Signalling Effects", Journal of Accounting and Economics, 28, pp. 1-25.

ANANDARAJAN, A., I. HASAN and A. LOZANO-VIVAS (2003). "The role of loan loss provisions in earnings management, capital management, and signalling: The Spanish experience", Advances in International Accounting, 16, pp. 43-63.

ARELLANO, M., and S. BOND (1991). "Some Test of Specification for Panel Data: Monte Carlo Evidence and Application to Employment Equations", Review of Economic Studies, 58, pp. 277-297.

- (1988). Dynamic Panel Data Estimation Using DPD - A Guide for Users, Working Paper No. 88/15, The Institute for Fiscal Studies.

AYUSO, J., D. PÉREZ and J. SAURINA (2004). "Are Capital Buffers Procyclical? Evidence from Spanish Panel Data", Journal of Financial Intermediation, Vol. 3, No. 2. Special Issue on Bank Capital Adequacy Regulation under the New Basel Accord.

BARNEA, A., J. RONEN and S. SADAN (1975). "The implementation of accounting objectives: an application to extraordinary items", Accounting Review, 50, January, pp. 58-68.

BCBS (2004). International Convergence of Capital Measurement and Capital Standards. A Revised Framework, June.

BEATTIE, V. A., P. D. CASSON, R. S. DALE, G. W. MCKENZIE, C. M. S. SUTCLIFFE and M. J. TURNER (1995). Banks and Bad Debts: Accounting for International Losses in International Banking, John Wiley \& Sons.

BEATTY, A., S. L. CHAMBERLAIN and J. MAGLIOLO (1995). "Managing Financial Reports of Commercial Banks: The Influence of Taxes, Regulatory Capital, and Earnings", Journal of Accounting Research, Vol. 33, No. 2, Autumn, pp. 231-261.

BEAVER, W. H., C. EGER, S. RYAN and M. WOLFSON (1989). "Financial reporting, supplemental disclosures and bank share price", Journal of Accounting Research, 27, Autumn, pp. 157-178.

BEAVER, W. H., and E. E. ENGLE (1996). "Discretionary behaviour with respect to allowance for loan losses and the behaviour of securities prices", Journal of Accounting and Economics, 22, August-December, pp. 177-206.

BENSTON, G. J., and L. D. WALL (2004). "How should banks account for loan losses?", Journal of Accounting and Public Policy, March-April.

— (2005). "How should banks account for loan losses?", Economic Review Fourth Quarter, Federal Reserve Bank of Atlanta.

BERGER, A. N., R. J. HERRING and G. P. SZEGÖ (1995). "The Role of Capital in Financial Institutions", Journal of Banking and Finance, 19, pp. 393-430.

COLLINS, J. H., D. A. SHACKELFORD and J. M. WAHLEN (1995). "Bank Differences in the Co-ordination of Regulatory Capital, Earnings, and Taxes”, Journal of Accounting Research, Vol. 33, No. 2 Autumn, pp. 263-291.

CROCKET, A. (1997). "The Theory and Practice of Financial Stability", Essays in International Finance, 203, April. Princeton University.

DYE, R. A. (1988). "Earnings Management in an Overlapping Generations Model", Journal of Accounting Research, Vol. 26, No. 2 Autumn, pp. 195-235.

EVANS, J. H., and S. S. SRIDHAR (1996). "Multiple Control Systems, Accrual Accounting, and Earnings Management", Journal of Accounting Research, Vol. 34, No. 1 Spring, pp. 45-65.

FERNÁNDEZ DE LIS, S., J. MARTíNEZ and J. SAURINA (2000). Credit growth, problem loans and credit risk provisioning in Spain, Working Paper No. 0018, Banco de España.

FUDENBERG, D., and J. TIROLE (1995). "A Theory of Income and Dividend Smoothing Based on Incumbency Rents", Journal of Political Economy, Vol. 103, No. 1, pp. 75-93.

GOEL, A. M., and A. V. THAKOR (2003). "Why do firms smooth earnings?", Journal of Business, Vol. 76, No. 1, pp. 151-192.

GREENAWALT, M. B., and J. SINKEY (1988). "Bank Loan-Loss Provisions and the Income-Smoothing Hypothesis: An Empirical Analysis, 1976-1984", Journal of Financial Services Research, 1, pp. 301-318.

HOLMSTROM, B., and J. TIROLE (2000). "Liquidity and risk management", Journal of Money, Credit and Banking, 32, pp. 295-319.

HUGHES, J. P., W. LANG, L. J. MESTER and C. MOON (1996). "Efficient Banking under Interstate Branching", Journal of Money, Credit and Banking, Vol. 28, No. 4, November, part 2, pp. 1045-1071.

JIMÉNEZ, G., and J. SAURINA (2006). Credit risk, credit cycles and prudential regulation, forthcoming, International Journal of Central Banking.

KANG, S., and K. SIVARAMAKRISHNAN (1995). "Issues in testing earnings management and an instrumental variable approach", Journal of Accounting Research, Vol. 33, No. 2, Autumn, pp. 353-367.

KIM, M., and W. KROSS (1998). "The impact of the 1989 change in bank capital standards on loan loss provisions and write-offs", Journal of Accounting and Economics, 25, February, pp. 69-99.

KIM, D., and A. SANTOMERO (1993). "Forecasting required loan loss reserves", Journal of Economics and Business, Vol. 45.

LAEVEN, L., and G. MAJNONI (2003). "Loan Loss Provisioning and Economic Slowdowns: Too Much, Too Late?", Journal of Financial Intermediation, 12, pp. 178-197.

LAMBERT, R. A. (1984). "Income Smoothing as Rational Equilibrium Behavior", The Accounting Review, Vol. LIX, No. 4 , October, pp. 604-618 
LIU, C., S. G. RYAN and J. M. WAHLEN (1997). "Differential valuation implications of loan loss provisions across banks and fiscal quarters", The Accounting Review, Vol. 72, 3, January, pp. 133-146.

MA, C. K. (1988). "Loan Loss Reserves and Income Smoothing: The Experience in the U.S. Banking Industry", Journal of Business Finance \& Accounting, 15 (4), Winter, pp. 487-497.

MANOVE, M., and A. J. PADILLA (1999). "Banking (Conservatively) with Optimists", Rand Journal of Economics, Vol. 30, No. 2, Summer, pp. 324-350.

MOYER, S. E. (1990). "Capital Adequacy ratio Regulations and Accounting Choices in Commercial Banks", Journal of Accounting and Economics, 13, pp. 123-154.

MYERS, S. C., and N. S. MAJLUF (1984). "Corporate Financing and Investment Decisions when Firms have Information that Investors do not Have", Journal of Financial Economics, 13, pp. 187-221.

RAJAN, R. G. (1994). "Why Bank Credit Policies Fluctuate: a Theory and Some Evidence", Quarterly Journal of Economics, Vol. CIX No. 2, May, pp. 399-441.

RONEN, J., and S. SADAN (1981). Smoothing Income Numbers: Objectives, Means, and Implications, Addison-Wesley Publishing Company.

ROZYCKI, J. J. (1997). "A tax motivation for smoothing earnings", Quarterly Review of Economics and Finance, 37, pp. 563-578.

SCHIPPER, K. (1989). "Commentary on Earnings Management", Accounting Horizons, December, pp. 92-106.

SCHOLES, M. S., G. P. WILSON and M. A. WOLFSON (1990). "Tax planning, regulatory capital planning, and financial reporting strategy for commercial banks", The Review of Financial Studies, Vol. 3, 4, pp. 625-650.

SHRIEVES, R. E., and D. DAHL (2003). "Discretionary accounting and the behaviour of Japanese banks under financial duress", Journal of Banking and Finance, 27, pp. 1219-1243.

TAYLOR, A., and C. A. E. GOODHART (2004). Procyclicality and volatility in the financial system: The implementation of Basel II and IAS 39, mimeo.

TRUEMAN, B., and B. TITMAN (1988). "An Explanation of Accounting Income Smoothing", Journal of Accounting Research, Vol. 26, Supplement, pp. 127-139.

WAHLEN, J. M. (1994). "The Nature of Information in Commercial Bank Loan Loss Disclosures", The Accounting Review, Vol. 69, No. 3, July, pp. 455-478.

WALL, L., and T. W. KOCH (2000). "Bank Loan-Loss Accounting: a Review of Theoretical and Empirical Evidence", Federal Reserve Bank of Atlanta Economic Review, Second Quarter, pp. 1-19.

WETMORE, J. L., and J. R. BRICK (1994). "Loan-Loss Provisions of Commercial Banks and Adequate Disclosure: A Note", Journal of Economics and Business, 46, pp. 299-305.

WINTER, R. A. (1994). "The Dynamics of Competitive Insurance Markets", Journal of Financial Intermediation, 3 , pp. $379-415$.

WORLD BANK (2002). "Bank Loan Classification and Provisioning Practices in Selected Developed and Emerging Countries", Finance Forum, June. 
Table 1. Summary statistics and definition of the variables used in the empirical analysis

Sample period: 1986-2002 (annual data).

Sample size: 1449 observations.

\begin{tabular}{|c|c|c|c|c|}
\hline & Mean & $\begin{array}{l}\text { Standard } \\
\text { Deviation }\end{array}$ & Minimum & Maximun \\
\hline CPLL & 0.40 & 0.42 & -1.12 & 3.56 \\
\hline$N P L$ & 1.99 & 1.46 & 0.00 & 12.62 \\
\hline IBOL & 442 & 264 & 208 & 1,012 \\
\hline LTA & 52.65 & 12.02 & 10.98 & 98.95 \\
\hline GDPG & 3.29 & 1.59 & -1.03 & 5.55 \\
\hline$C A P$ & 11.27 & 3.34 & 1.87 & 47.58 \\
\hline CAPT1 & 10.01 & 3.52 & 1.30 & 47.58 \\
\hline BUF & 40.86 & 41.72 & -76.60 & 494.75 \\
\hline NOI & 1.42 & 0.81 & -4.77 & 5.65 \\
\hline$A B S\left(N^{\prime} I_{i t}-N O I_{i}\right)$ & 0.40 & 0.39 & 0.00 & 5.61 \\
\hline SIZE & 14.48 & 1.59 & 10.01 & 19.73 \\
\hline
\end{tabular}

CPLL: ratio of total net specific and general loan loss provisions over total assets.

NPL: ratio of doubtful assets over total assets.

IBOL: general index of the Madrid Stock Exchange.

LTA: ratio of total loans over total assets.

GDPG: GDP growth.

$\boldsymbol{C A P}$ : total capital ratio (regulatory capital over risk-weighted assets).

CAPT1: Tier 1 ratio (Tier 1 capital over risk-weighted assets).

BUF: capital buffer (the relative excess of capital hold by the bank over the minimum regulatory requirements).

NOI: ratio of net income before provisions, extraordinary items and taxes over total assets.

$\boldsymbol{A B S}\left(\mathbf{N O I}_{i t}-\mathbf{N O I}_{i}\right)$ : absolute value of the difference between the net operating income of bank $\mathrm{i}$ in period $\mathrm{t}$ and the average net operating income of bank $\mathrm{i}$ over the period.

SIZE: log of total assets. 
Table 2. Estimation of the model of determinants of loan loss provisions charged by Spanish banks

Dependent variable: CPLLit

Estimation method: GMM, equation in first differences.

\begin{tabular}{|c|c|c|c|c|c|}
\hline $\begin{array}{l}\text { Explanatory } \\
\text { variables }\end{array}$ & Model 1 & Model 2 & Model 3 & Model 4 & Model 5 \\
\hline$N P L_{i t}$ & $\begin{array}{l}0.127^{* * *} \\
(0.000)\end{array}$ & $\begin{array}{l}0.116^{* * *} \\
(0.003)\end{array}$ & $\begin{array}{l}0.129^{* * *} \\
(0.000)\end{array}$ & $\begin{array}{l}0.124^{* * *} \\
(0.000)\end{array}$ & $\begin{array}{l}0.125^{\star * *} \\
(0.000)\end{array}$ \\
\hline$I B O L_{i t}$ & $\begin{array}{r}-0.000 \\
(0.111)\end{array}$ & $\begin{array}{r}-0.000 \\
(0.116)\end{array}$ & $\begin{array}{r}-0.000 \\
(0.109)\end{array}$ & $\begin{array}{r}-0.000 \\
(0.134)\end{array}$ & $\begin{array}{r}-0.000 \\
(0.180)\end{array}$ \\
\hline$L T A_{i t}$ & $\begin{array}{l}0.008^{\star *} \\
(0.013)\end{array}$ & $\begin{array}{l}0.012^{\star *} \\
(0.013)\end{array}$ & $\begin{array}{l}0.008^{* *} \\
(0.011)\end{array}$ & $\begin{array}{l}0.007^{\star *} \\
(0.026)\end{array}$ & $\begin{array}{l}0.007^{\star *} \\
(0.014)\end{array}$ \\
\hline GDPG $_{i t}$ & $\begin{array}{l}-0.042^{* *} \\
(0.030)\end{array}$ & $\begin{array}{l}-0.047^{\star *} \\
(0.029)\end{array}$ & $\begin{array}{l}-0.042^{* *} \\
(0.030)\end{array}$ & $\begin{array}{l}-0.046^{* *} \\
(0.025)\end{array}$ & $\begin{array}{l}-0.045^{\star *} \\
(0.019)\end{array}$ \\
\hline$C A P_{i t-1}$ & $\begin{array}{r}-0.008 \\
(0.345)\end{array}$ & $\begin{array}{r}-0.006 \\
(0.652)\end{array}$ & -- & -- & $\begin{array}{r}-0.007 \\
(0.424)\end{array}$ \\
\hline CAPT $_{i t-1}$ & -- & -- & $\begin{array}{r}-0.006 \\
(0.569)\end{array}$ & -- & -- \\
\hline$B U F_{i t-1}$ & -- & -- & -- & $\begin{array}{r}-0.001 \\
(0.185)\end{array}$ & -- \\
\hline $\mathrm{NOI}_{i t}$ & $\begin{array}{l}0.169^{* * *} \\
(0.008)\end{array}$ & $\begin{array}{l}0.166^{* *} \\
(0.022)\end{array}$ & $\begin{array}{l}0.170^{* * *} \\
(0.009)\end{array}$ & $\begin{array}{l}0.142^{* *} \\
(0.026)\end{array}$ & $\begin{array}{l}0.159^{* *} \\
(0.015)\end{array}$ \\
\hline $\mathrm{NOI}_{i t}{ }^{*} R E G 00$ & $\begin{array}{l}-0.094^{* * *} \\
(0.005)\end{array}$ & -- & $\begin{array}{l}-0.092^{* * *} \\
(0.008)\end{array}$ & $\begin{array}{l}-0.098^{* * *} \\
(0.008)\end{array}$ & $\begin{array}{l}-0.106^{* * *} \\
(0.002)\end{array}$ \\
\hline$A B S\left(N O I_{i t}-N^{\prime} I_{i}\right)$ & -- & -- & -- & -- & $\begin{array}{l}0.103 \\
(0.140)\end{array}$ \\
\hline SIZE $_{i t}$ & $\begin{array}{r}-0.068 \\
(0.494) \\
\end{array}$ & $\begin{array}{r}-0.040 \\
(0.742) \\
\end{array}$ & $\begin{array}{r}-0.070 \\
(0.489) \\
\end{array}$ & $\begin{array}{r}-0.072 \\
(0.495) \\
\end{array}$ & $\begin{array}{r}-0.063 \\
(0.521) \\
\end{array}$ \\
\hline m1 & $\begin{array}{l}-3.440^{\star \star *} \\
(0.001)\end{array}$ & $\begin{array}{l}-2.986^{\star * *} \\
(0.003)\end{array}$ & $\begin{array}{l}-3.422^{* \star *} \\
(0.001)\end{array}$ & $\begin{array}{l}-3.486^{* \star *} \\
(0.000)\end{array}$ & $\begin{array}{l}-3.341^{* * *} \\
(0.001)\end{array}$ \\
\hline m2 & $\begin{array}{r}-1.176 \\
(0.240)\end{array}$ & $\begin{array}{r}-1.198 \\
(0.231)\end{array}$ & $\begin{array}{r}-1.187 \\
(0.235)\end{array}$ & $\begin{array}{r}-1.122 \\
(0.262)\end{array}$ & $\begin{array}{r}-0.904 \\
(0.366)\end{array}$ \\
\hline Sargan test & $\begin{array}{l}87.98 \\
(0.279) \\
\end{array}$ & $\begin{array}{l}89.03 \\
(0.333) \\
\end{array}$ & $\begin{array}{l}84.86 \\
(0.363) \\
\end{array}$ & $\begin{array}{l}88.53 \\
(0.266) \\
\end{array}$ & $\begin{array}{r}89.22 \\
(0.249) \\
\end{array}$ \\
\hline Period & $1989-2002$ & 1989-1999 & 1989-2002 & 1989-2002 & $1989-2002$ \\
\hline $\mathrm{N}^{\circ}$ Obs. & 1029 & 829 & 1029 & 1029 & 1029 \\
\hline
\end{tabular}

Notes:

- Variables as defined in Table 1.

- m1 and m2 stand for first- and second-order residual autocorrelation, based on estimates of the residuals in first differences.

- IBOL, GDPG and SIZE are considered exogenous.

-Instruments for the endogenous variables: GMM with lags 2 to 3 for NPL, LTA and CAP. NOI, $N O{ }^{*} R E G O O$ and $A B S\left(N O l_{i t}-N O l_{i}\right)$ are instrumented with lag 2. All instruments selected as in DPD [Arellano and Bond (1991)].

${ }^{\star \star \star \star},{ }^{\star \star}$ and ${ }^{*}$ denote significance at $1 \%, 5 \%$ and $10 \%$, respectively. P-values in brackets. 
Table 3. Robustness analysis for the estimation of determinants of loan loss provisions charged by Spanish banks

Dependent variable: CPLLit

Estimation method: GMM in first differences models 1 and 2.

\begin{tabular}{|c|c|c|}
\hline $\begin{array}{l}\text { Explanatory } \\
\text { variables }\end{array}$ & Model 1 & Model 2 \\
\hline$C P L L_{i t-1}$ & $\begin{array}{l}0.183^{* * *} \\
(0.000)\end{array}$ & -- \\
\hline$N P L_{i t}$ & $\begin{array}{l}0.113^{* * *} \\
(0.000)\end{array}$ & $\begin{array}{l}0.124^{* * *} \\
(0.000)\end{array}$ \\
\hline$I B O L_{i t}$ & $\begin{array}{r}-0.000 \\
(0.210)\end{array}$ & $\begin{array}{r}-0.000 \\
(0.152)\end{array}$ \\
\hline$L T A_{i t}$ & $\begin{array}{l}0.010^{* * *} \\
(0.000)\end{array}$ & $\begin{array}{l}0.008^{* *} \\
(0.014)\end{array}$ \\
\hline GDPG $_{i t}$ & $\begin{array}{c}-0.033^{*} \\
(0.077)\end{array}$ & $\begin{array}{c}-0.048^{* *} \\
(0.013)\end{array}$ \\
\hline$C A P_{i t-1}$ & $\begin{array}{r}-0.011 \\
(0.198)\end{array}$ & -- \\
\hline $\mathrm{CAP}_{i t}$ & -- & $\begin{array}{c}-0.021^{* *} \\
(0.016)\end{array}$ \\
\hline $\mathrm{NOI}_{i t}$ & $\begin{array}{l}0.259^{* * *} \\
(0.003)\end{array}$ & $\begin{array}{l}0.158^{* *} \\
(0.013)\end{array}$ \\
\hline NOI it ${ }^{*} R E G 00$ & $\begin{array}{c}-0.098^{* * *} \\
(0.003)\end{array}$ & $\begin{array}{l}-0.111^{* * *} \\
(0.001)\end{array}$ \\
\hline$S I Z E_{i t}$ & $\begin{array}{r}-0.019 \\
(0.849) \\
\end{array}$ & $\begin{array}{r}-0.072 \\
(0.442) \\
\end{array}$ \\
\hline $\mathrm{m1}$ & $\begin{array}{c}-3.539^{\star * \star} \\
(0.000)\end{array}$ & $\begin{array}{c}-3.448^{* * *} \\
(0.001)\end{array}$ \\
\hline $\mathrm{m} 2$ & $\begin{array}{r}-0.101 \\
(0.919)\end{array}$ & $\begin{array}{r}-1.027 \\
(0.305)\end{array}$ \\
\hline Sargan test & $\begin{array}{c}114.71 \\
(0.311) \\
\end{array}$ & $\begin{array}{c}86.34 \\
(0.322) \\
\end{array}$ \\
\hline Period & $1989-2002$ & $1989-2002$ \\
\hline No Obs. & 1029 & 1029 \\
\hline
\end{tabular}

Notes:

- Variables are defined in Table 1.

- $\mathrm{m} 1$ and $\mathrm{m} 2$ stand for first- and second-order residual autocorrelation tests, based on estimates of the residuals in first differences.

- IBOL, GDPG, and SIZE are considered exogenous.

- Instruments for the endogenous variables: GMM with lags 2 to 3 for $C A P, C P L L_{i t-1}, N P L$ and LTA. NOI and $N O I^{*} R E G O O$ are instrumented with lag 2. All instruments selected as in DPD [Arellano and Bond (1991)].

${ }^{* \star * \star},{ }^{* \star}$ and ${ }^{\star}$ denote significance at $1 \%, 5 \%$ and $10 \%$, respectively. P-values in brackets. 
BANCO DE ESPAÑA PUBLICATIONS

\section{WORKING PAPERS ${ }^{1}$}

0527 LUIS J. ÁLVAREZ, PABLO BURRIEL AND IGNACIO HERNANDO: Price setting behaviour in Spain: evidence from micro PPI data.

0528 EMMANUEL DHYNE, LUIS J. ÁLVAREZ, HERVÉ LE BIHAN, GIOVANNI VERONESE, DANIEL DIAS, JOHANNES HOFFMANN, NICOLE JONKER, PATRICK LÜNNEMANN, FABIO RUMLER AND JOUKO VILMUNEN: Price setting in the euro area: some stylized facts from individual consumer price data.

0529 TERESA SASTRE AND JOSÉ LUIS FERNÁNDEZ-SÁNCHEZ: Un modelo empírico de las decisiones de gasto de las familias españolas.

0530 ALFREDO MARTÍN-OLIVER, VICENTE SALAS-FUMÁS AND JESÚS SAURINA: A test of the law of one price in retail banking.

0531 GABRIEL JIMÉNEZ AND JESÚS SAURINA: Credit cycles, credit risk, and prudential regulation.

0532 BEATRIZ DE-BLAS-PÉREZ: Exchange rate dynamics in economies with portfolio rigidities.

0533 ÓSCAR J. ARCE: Reflections on fiscalist divergent price-paths.

0534 M. ${ }^{a}$ DE LOS LLANOS MATEA AND MIGUEL PÉREZ: Differences in changes in fresh food prices by type of establishment. (The Spanish original of this publication has the same number.)

0535 JOSÉ MANUEL MARQUÉS, FERNANDO NIETO AND ANA DEL RíO: Una aproximación a los determinantes de la financiación de las sociedades no financieras en España.

0536 S. FABIANI, M. DRUANT, I. HERNANDO, C. KWAPIL, B. LANDAU, C. LOUPIAS, F. MARTINS, T. MATHÄ, R. SABBATINI, H. STAHL AND A. STOKMAN: The pricing behaviour of firms in the euro area: new survey evidence.

0537 LUIS J. ÁLVAREZ AND I. HERNANDO: The price setting behaviour of Spanish firms: evidence from survey data.

0538 JOSÉ MANUEL CAMPA, LINDA S. GOLDBERG AND JOSÉ M. GONZÁLEZ-MíNGUEZ: Exchange-rate pass-through to import prices in the euro area.

0539 RAQUEL LAGO-GONZÁLEZ AND VICENTE SALAS-FUMÁS: Market power and bank interest rate adjustments.

0540 FERNANDO RESTOY AND ROSA RODRÍGUEZ: Can fundamentals explain cross-country correlations of asset returns?

0541 FRANCISCO ALONSO AND ROBERTO BLANCO: Is the volatility of the EONIA transmitted to longer-term euro money market interest rates?

0542 LUIS J. ÁLVAREZ, EMMANUEL DHYNE, MARCO M. HOEBERICHTS, CLAUDIA KWAPIL, HERVÉ LE BIHAN, PATRICK LÜNNEMANN, FERNANDO MARTINS, ROBERTO SABBATINI, HARALD STAHL, PHILIP VERMEULEN AND JOUKO VILMUNEN: Sticky prices in the euro area: a summary of new micro evidence.

0601 ARTURO GALINDO, ALEJANDRO IZQUIERDO AND JOSÉ MANUEL MONTERO: Real exchange rates, dollarization and industrial employment in Latin America.

0602 JUAN A. ROJAS AND CARLOS URRUTIA: Social security reform with uninsurable income risk and endogenous borrowing constraints.

0603 CRISTINA BARCELÓ: Housing tenure and labour mobility: a comparison across European countries.

0604 FRANCISCO DE CASTRO AND PABLO HERNÁNDEZ DE COS: The economic effects of exogenous fiscal shocks in Spain: a SVAR approach.

0605 RICARDO GIMENO AND CARMEN MARTÍNEZ-CARRASCAL: The interaction between house prices and loans for house purchase. The Spanish case.

0606 JAVIER DELGADO, VICENTE SALAS AND JESÚS SAURINA: The joint size and ownership specialization in banks' lending.

0607 ÓSCAR J. ARCE: Speculative hyperinflations: When can we rule them out?

0608 PALOMA LÓPEZ-GARCÍA AND SERGIO PUENTE: Business demography in Spain: determinants of firm survival.

0609 JUAN AYUSO AND FERNANDO RESTOY: House prices and rents in Spain: Does the discount factor matter?

0610 ÓSCAR J. ARCE AND J. DAVID LÓPEZ-SALIDO: House prices, rents, and interest rates under collateral constraints.

0611 ENRIQUE ALBEROLA AND JOSÉ MANUEL MONTERO: Debt sustainability and procyclical fiscal policies in Latin America.

1. Previously published Working Papers are listed in the Banco de España publications calalogue. 
0612 GABRIEL JIMÉNEZ, VICENTE SALAS AND JESÚS SAURINA: Credit market competition, collateral and firms' finance.

0613 ÁNGEL GAVILÁN: Wage inequality, segregation by skill and the price of capital in an assignment model.

0614 DANIEL PÉREZ, VICENTE SALAS AND JESÚS SAURINA: Earnings and capital management in alternative loan loss provision regulatory regimes.

\begin{tabular}{|c|c|}
\hline BANCODEESPAÑA & $\begin{array}{c}\text { Unidad de Publicaciones } \\
\text { Alcalá, 522; 28027 Madrid } \\
\text { Telephone +34 } 913386363 \text {. Fax +34 } 913386488 \\
\text { e-mail: Publicaciones@bde.es } \\
\text { www.bde.es }\end{array}$ \\
\hline
\end{tabular}




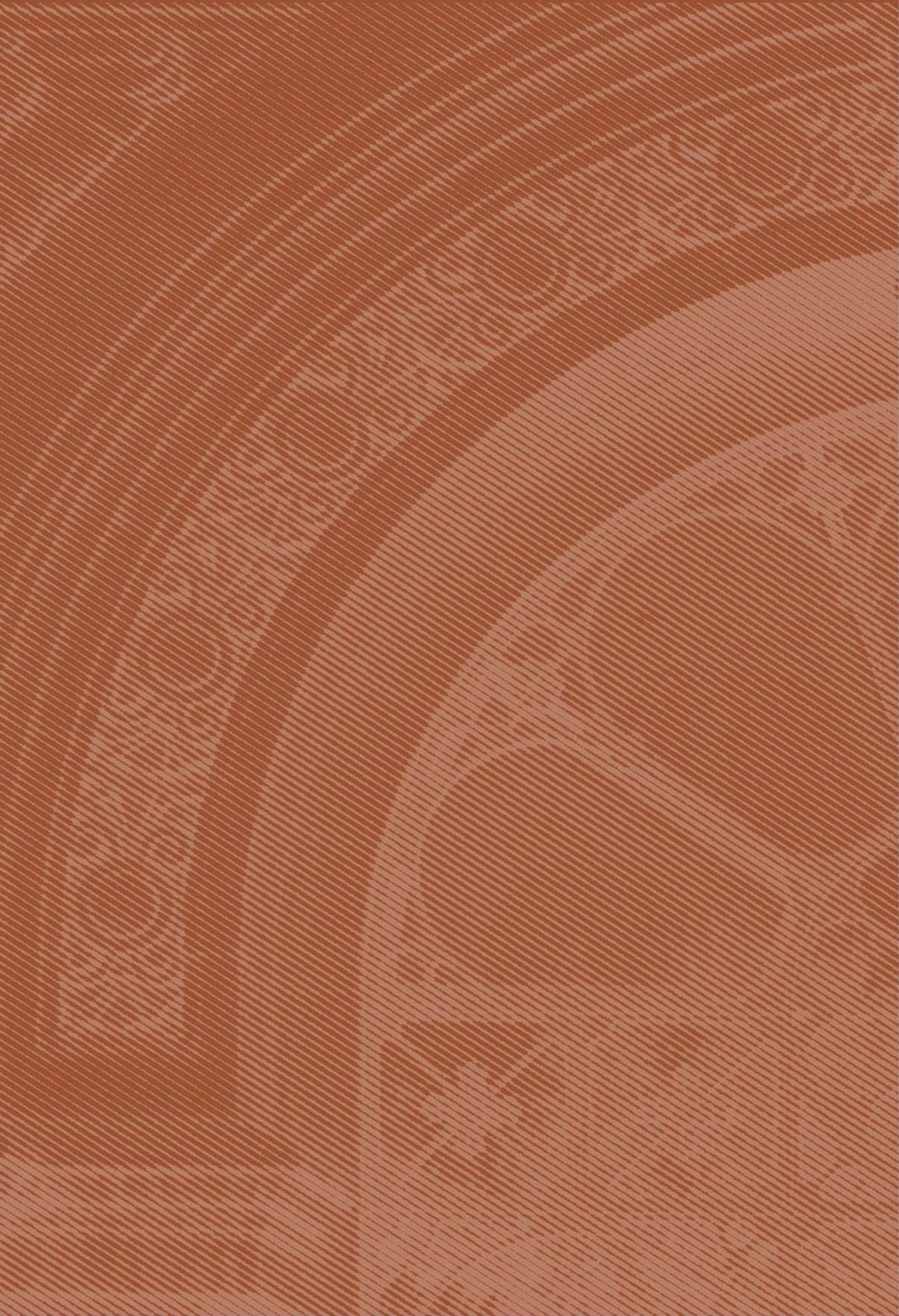

